\title{
THE ONE-EIGHTH RELATIONSHIP THAT CONSTRAINS DEGLACIAL SEISMICITY AND CAVE DEVELOPMENT IN CALEDONIDE MARBLES
}

\author{
DEGLACIALNA SEIZMIČNOST IN RAZVOJ JAM V KALEDONSKIH \\ MARMORJIH: RAZMERJE ENA PROTI OSEM
}

\author{
Trevor FAULKNER ${ }^{1}$
}

\begin{abstract}
UDC $550.34: 551.44(234.652)$

Trevor Faulkner: The one-eighth relationship that constrains deglacial seismicity and cave development in Caledonide marbles

The formation of karst caves in Caledonide metamorphic limestones in a repeatedly-glaciated $40000 \mathrm{~km}^{2}$ region in central Scandinavia was initiated by tectonic inception, a process in which open fracture routes, primarily created by deglacial seismicity, provided the opportunity for subsequent dissolution and enlargement into cave passages in both deglacial and interglacial environments. The tectonic inception model built on reports of a 'partially detached' thin upper crustal layer in similar settings in Scotland and this paper shows that the present maximum subsurface cave distance (i.e. the distance of a passage to the nearest land surface) is commonly less than one-eighth of the depth of the local glaciated valley. This suggests that fracture generation was related to the scale of isostatic uplift and was partly determined by the magnitude of seismicity caused by the differential pressure change and differential uplift that occurred along valley walls as the ice margin of each of the major Pleistocene icesheets receded from west to east. The maximum one-eighth relationship is also commonly maintained in other Caledonide marble terranes in Scandinavia, Scotland and New England (USA), suggesting that many of the caves in these areas were formed by similar processes.

Key words: Caledonide, deglacial speleogenesis, epigean, ice margin, inception fracture, marble, neotectonics, one-eighth relationship, seismicity, stripe karst, subsurface cave distance, tectonic inception, Weichselian, Scandinavia.
\end{abstract}

Izvleček UDK $550.34: 551.44(234.652)$

Trevor Faulkner: Deglacialna seizmičnost in razvoj jam v kaledonskih marmorjih: razmerje ena proti osem

Razvoj jam v kaledonskih marmorjih na periodično poledenelem $40000 \mathrm{~km}^{2}$ velikem območju osrednje Skandinavije se je začel s tektonskim začetjem, procesom pri katerem so se prvotne prevodne razpoke ustvarile zaradi razbremenitev ob umikih ledenikov. Vzdolž teh prevodnih poti se v obdobju umikanja ledenikov in medledenih dobah razvijajo kraški kanali. Model tektonske incepcije, ki obravnava razvoj jam v "delno ločenem" vrhnjem delu skorje, temelji na opažanjih, da je največja globina jamskih rovov ( pri tem je mišljena razdalja med površino in rovom) manjša od osmine globine lokalne ledeniške doline. To nakazuje, da je nastanek prevodnih razpok povezan $\mathrm{z}$ izostatičnim dvigom in delno pogojen $\mathrm{z}$ velikostjo seizmičnosti, ki so jo povzročili diferencialni pritiski in dvigi, ki so nastali ob ledeniških dolinah med umikanjem ledeniških pokrovov v smeri od zahoda proti vzhodu. Razmerje ena proti osem je značilno tudi v drugih območjih kaledonskih marmorjev v Skandinaviji, na Škotskem in v Novi Angliji (ZDA), kar kaže, da so podobni procesi botrovali nastanku številnih jam na teh območjih.

Ključne besede: Kaledonidi, deglacialna speleogeneza, podzemlje, rob ledu, incepcijske razpoke, marmor, neotektonika, razmerje ena proti osem, seizmičnost, kras v pasovih, razdalja površje-jama, tektonska incepcija, Weichselian, Skandinavija.

\footnotetext{
${ }^{1}$ Limestone Research Group, School of Geography, The University of Birmingham, Birmingham, B15 2TT, UK,

e-mail: trevor@marblecaves.org.uk
}

Received/Prejeto: 23.06.2006 


\section{INTRODUCTION}

The repeatedly-glaciated $40000 \mathrm{~km}^{2}$ study area in central Scandinavia contains over 1000 individual metamorphic limestone (marble) outcrops and has nearly 1000 recorded karst caves with a total passage length $>72 \mathrm{~km}$ (Faulkner, 2005 and 2006a, Fig. 1; Fig. 1). Fundamental differences between these caves and those formed in sedimentary limestones derive from the metamorphic grade of the host bedrock with its very low primary porosity and from the fine-scale foliations and the consequent lack of partings guided by the initial bedding. Indeed, the foliation is commonly vertical in the western part of the study area, where sub-horizontal openings must be along joints or other fractures in the marble that has been metamorphosed up to amphibolite grade. The deepest cave is only $180 \mathrm{~m}$ deep, despite outcrop vertical ranges reaching over $900 \mathrm{~m}$. Caves tend to cluster together and are positioned randomly in the vertical dimension, whilst commonly remaining within $50 \mathrm{~m}$ of the overlying surface. Additionally, there are no regional-scale caves. This is despite some narrow marble outcrops being several tens of kilometres in length, forming stripe karsts. Commonly, just a single streamway underlies upper-level relict phreatic passages with few vadose elements, creating an upside-down, vadose-beneath-phreatic, morphology. Recharge to the karst is primarily allogenic and cave stream discharges commonly remain unsaturated with calcite (Lauritzen, 1981; Bakalowicz, 1984). Autogenic recharge is relatively insignificant, mainly occurring during the spring snowmelt. These caves have their own morphological style, recognisable right across the area, which differentiates them from caves formed in 'classical' karsts in sedimentary limestones. Because the caves are relatively short and epigean and there is a complete absence of long, hypogean, cave systems, speleogenesis by the (chemical) inception horizon hypothesis (Lowe 1992; Lowe \& Gunn 1997) is unlikely.

The tectonic inception model (Faulkner 2005; 2006a) proposed that it is only open fracture routes that could provide the opportunity for dissolution and enlargement into cave passages in the Caledonide marbles. It was hypothesised that the dimensions of these fractures are related to the magnitude, and perhaps to the frequency, of local earthquakes and commonly-small tectonic movements that arose from the isostatic rebound that accompanied deglaciation at the end of each major Pleistocene glacial. Faulkner (2006a) described in detail the evidence for deglacially-induced earthquakes at the end of the Weichselian glaciation in Scandinavia. An additional mechanism for fracture generation may arise from earthquakes caused by the downhill sliding of a glacial ice mass (Ekström et al. 2003). The tectonic openings formed 
along inception surfaces between the marble and adjacent aquicludes and at inception fractures that are entirely within the marble and are commonly (though not universally) parallel to, or orthogonal to, the foliation. The model built on reports of a 'partially detached' thin upper crustal layer in similar settings in Scotland (Davenport et al. 1989). It is supported by observations of later neotectonic movements in most relict cave passages and sporadically on the surface from evidence such as fault gouges, slickensides and sharp edges that produce long narrow shadows. This paper explores relationships between cave dimensions and their local external geological and geomorphological attributes, providing more evidence in support of the model.

\section{NEOTECTONICS AND CAVES}

The areas of Scandinavia that are seismically the most active at present are the south Norway coast area, which has few carbonate outcrops, and that part of the county of Nordland in Norway that is north of the study area. That northern area, from Mo i Rana to Narvik, has caves up to $20 \mathrm{~km}$ in length and up to $580 \mathrm{~m}$ in vertical range (VR). In contrast, the study area may have a comparable density of karst caves, but with lengths and VRs only up to $5.6 \mathrm{~km}$ and $180 \mathrm{~m}$ (Faulkner 2005). The neotectonics map (Fig. 1) after Dehls et al. (2000) thus seems to suggest a rough relationship between the frequency and magnitude of earthquakes, and the dimensions of karst caves in a region. It is therefore hypothesised that the depths of inception fractures below the surface, and hence the total lengths of potential proto-conduits, are related to the magnitude, and perhaps to the frequency, of local deglacial earthquakes, assuming some correlation with the neotectonic pattern. Because that seismicity was related to the scale of isostatic uplift and to the differential pressure change that occurs along valley walls as a major icesheet recedes (Davenport et al. 1989; Ringrose et al. 1991), it follows that cave depth and length = function (fracture depth and extent) $=$ function (strength of tec- tonic activity) $=$ function (change of ice thickness during deglaciation).

From the above conclusion, the caves with the greatest dimensions should lie along the Swedish border area, because the icesheet was thickest there during each glaciation (probably $\sim 2 \mathrm{~km}$ thick at the Last Glacial Maximum, covering all the local peaks) and because there are deep glacial valleys with extensive stripe karst outcrops. This setting should cause the largest earthquakes at the end of each Pleistocene deglaciation, and therefore the most extensive and deepest set of fractures. This may account, at least in part, for the presence near the border of four of the five longest caves of the study area: Korallgrottan (Sweden: $5.6 \mathrm{~km}$ ), Labyrintgrottan (Sweden: $2.6 \mathrm{~km}$ ), Stor Grubblandsgrotta (Norway: $1.9 \mathrm{~km}$ ) and Sotsbäcksgrottan (Sweden: $1.9 \mathrm{~km}$ ). The three deepest caves also lie in this region: Ytterlihullet (Norway: $180 \mathrm{~m})$, Korallgrottan $(144 \mathrm{~m})$ and Sotsbäcksgrottan $(110 \mathrm{~m})$. One other long and deep cave, Toerfjellhola (Norway: $1.9 \mathrm{~km}$ and $101 \mathrm{~m}$ ), lies along the flank of a major mountain ridge that runs parallel to the coast.

\section{SUBSURFACE CAVE DISTANCE}

Faulkner (2006a) discussed the shallow nature of most cave systems in the study area, suggesting that caves in stripe karsts have formed entirely within an upper zone of fractured rock. It was hypothesised above that there is a relationship between cave VR (which is the vertical difference between the highest and lowest explored points of a cave) and the local change of ice thickness during deglaciation. A more direct relationship is likely to be with the maximum distance of cave passages from the overlying surface. This subsurface cave distance is taken to be the length along a line orthogonal to the surface and the centre of any intersected passage (Fig. 2), which, in the extreme case of a cave passage behind a vertical cliff, could be a horizontal distance.

In order to test the distance and relief relationship, the maximum subsurface cave distances of 39 of the deeper caves of the study area (obtained from cave survey sections) were plotted against the local relief differences (Fig. 3). The local relief differences were taken from 1:50000 topographical maps by measuring the height above the valley floor of the local ridge-shoulder, where a consistently steep slope profile becomes less steep. Caves can occur at any altitude along this profile, and the total lengths of the profiles were always less than a few kilome- 


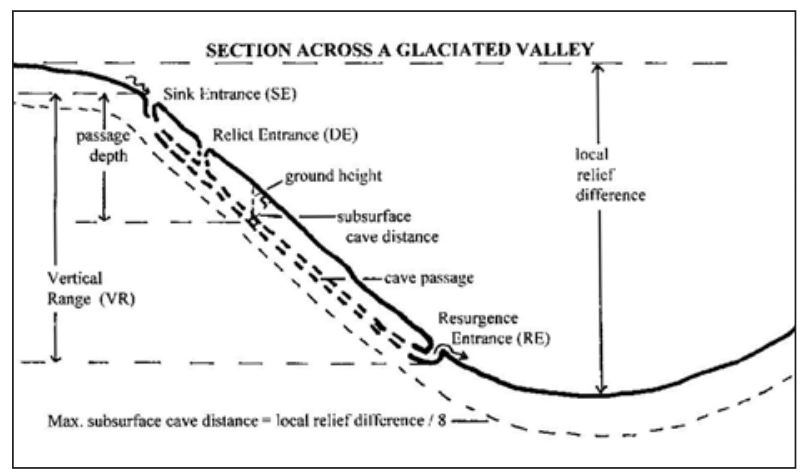

Fig. 2: Subsurface cave distance and other terms.

tres. There are few caves in areas of local relief difference of less than $100 \mathrm{~m}$, and none of these have VR>10 m.

The complete scatter diagram for all 884 recorded caves would show a poor correlation between subsurface cave distance and the local relief difference, because the mean VR of the caves is only $8.8 \mathrm{~m}$ and they occur in valleys of many different depths. However, Fig. 3 shows that the maximum distance of cave passages (and therefore of dissolutionally-enlarged inception fractures) from the surface is commonly one-eighth, or less, of the extent of the change of local relief. This maximum envelope for the relationship of subsurface cave distance to local relief difference appears to be approximately linear, at least for a local vertical relief of up to $400 \mathrm{~m}$, and perhaps up to

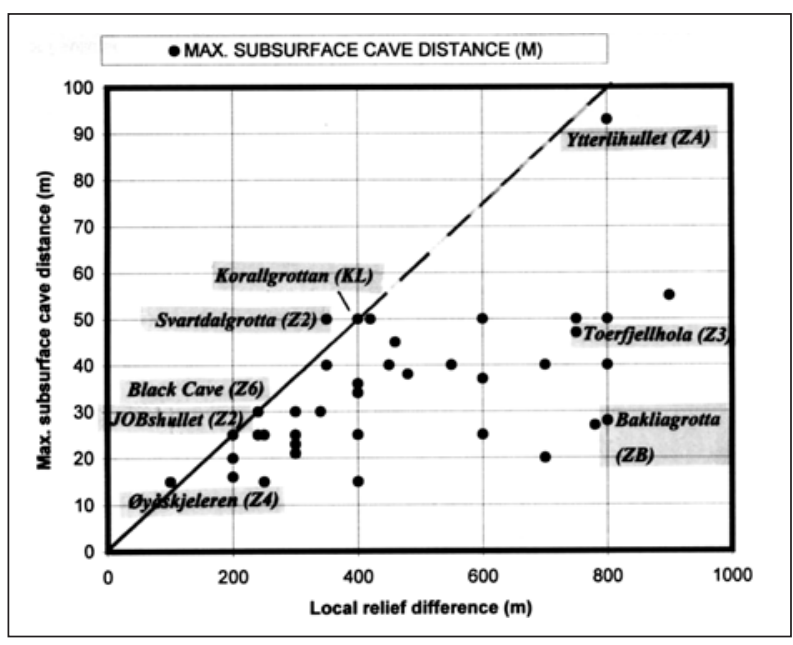

Fig. 3: Relationship between maximum subsurface cave distance and local relief difference. The straight line indicates the maximum one-eighth relationship that constrains nearly all the known caves in central Scandinavia, of which 39 of the deeper caves are indicated. The codes in parentheses give the geological zones used by Faulkner (2005). Z1-Z8, ZA-ZC and KL are located progressively eastward into Sweden. The wide geographical spread suggests that the maximum relationship applies throughout the study area.

$800 \mathrm{~m}$. Most parts of the study area are represented by the caves shown in Fig. 3, showing that the one-eighth relationship probably applies across the whole area.

\section{THE INFLUENCE OF EXTERNAL ATTRIBUTES ON INCEPTION FRACTURES}

The relationship between seismicity and cave development is supported by the evidence summarised by Faulkner (2005) and in Table 1. The karst type, for which three ranges of foliation dip were defined, influences the mean VR for the study area caves, but in a manner that is perhaps paradoxical. Thus, caves in Low Angle Karst (LAK, foliation dip $0-30^{\circ}$ ) tend to be deeper than average, caves in Angled Stripe Karst (ASK, 31-80 $0^{\circ}$ ) have a similar mean VR to that of all 884 recorded karst caves, and caves in Vertical Stripe Karst (VSK, 81-90 ${ }^{\circ}$ ) have a smaller mean VR. However, other cave dimensions vary less consistently with karst type.

Those caves in close proximity to a major thrust zone (designation $\mathrm{T}=1$ ) have larger-than-average mean dimensions, whereas those in close proximity to a major igneous pluton, and therefore in marble 'remetamorphosed' by contact metamorphism (designation $\mathrm{R}=1$ ) tend to be smaller. If the enhancing relationships are, in fact, directly controlled by the thrust attribute (rather than this just acting as a proxy for some other control- ling variable), then this implies that the reactivation of old thrusts by deglacial seismic shocks promotes fracturing in any adjacent marble outcrops, creating longer and deeper voids for cave inception. Two mechanisms are possible to explain the restricting case. Firstly, the previous high-temperature contact metamorphism of metalimestone may reduce its fracturing ability, by making the rock more homogeneous. Secondly, the presence of a large igneous pluton (such as occur in the Helgeland Nappe Complex in the west: Faulkner, 2006a, Fig. 1) may, of itself, reduce the magnitude of local earthquakes, and, therefore, their ability to create long and deep fractures. Of the six caves discussed previously, three occur disproportionately near a major thrust zone, and none lie in an outcrop subjected to contact metamorphism (the main country rock being mica schist), again lending support to the earthquake relationship hypothesis.

The percentages of the 39 deep caves in Fig. 3 with external attributes $\mathrm{R}=1$ or $\mathrm{T}=1$ were compared with the same percentages in the total set of 884 recorded caves 


\begin{tabular}{|l|l|l|l|l|}
\hline External attribute & Mean VR $<8.8 m$ & Mean VR c. 8.8 $m$ & Mean VR $>8.8 m$ & Notes \\
\hline Karst Type & VSK & ASK & LAK & $\begin{array}{l}\text { Other cave dimensions } \\
\text { (length, volume and cross- } \\
\text { section) vary }\end{array}$ \\
\hline $\begin{array}{l}\text { Contact } \\
\text { metamorphism (R) }\end{array}$ & $\mathrm{R}=1$ & $\mathrm{R}=0$ & $\begin{array}{l}\text { Similar for all cave } \\
\text { dimensions }\end{array}$ \\
\hline Thrust proximity (T) & $\mathrm{T}=0$ & $\mathrm{~T}=1$ & $\begin{array}{l}\text { Similar for all cave } \\
\text { dimensions }\end{array}$ \\
\hline $\begin{array}{l}\text { Cave Location } \\
\text { (as defined by } \\
\text { Faulkner, 2005) }\end{array}$ & $\begin{array}{l}\text { Coastal, Valley } \\
\text { Floor and Paleic } \\
\text { Surface }\end{array}$ & $\begin{array}{l}\text { Gently Sloping and } \\
\text { Valley Wall }\end{array}$ & $\begin{array}{l}\text { Ridge and Valley } \\
\text { Shoulder }\end{array}$ & $\begin{array}{l}\text { Locations in bold have } \\
\text { similar influences for mean } \\
\text { length and mean volume }\end{array}$ \\
\hline
\end{tabular}

Tab. 1: External attribute influences on mean cave vertical range. VSK: Vertical Stripe Karst, ASK: Angled Stripe Karst, LAK: Low Angle Karst.

in the study area. $\mathrm{R}=1$ only occurs in $18 \%$ of the 39 caves compared with $23 \%$ overall and $\mathrm{T}=1$ occurs rather more often (13\%, compared with $11 \%)$. Although these percentages may be statistically similar, the differences at least suggest that the individual attributes that promote the deeper caves towards the one-eighth limit of the distance / relief relationship are the same as the attributes that influence vertical range, as shown in Table 1. Furthermore, caves lying below coastal, valley floor and paleic surface (i.e. one that has hardly been modified by glaciation) locations are under-represented by the 39 deep caves, caves beneath gently sloping and valley wall locations are similarly represented, and caves in ridge and valley shoulder locations have two to three times the representation. Thus, the steeper is the local topography at the cave location (as defined by Faulkner 2005), then the more likely a deeper cave will be formed.

The proximity of the caves in Fig. 3 to the oneeighth 'limit' can be considered in terms of the competition between their various external attributes. Only Øyåskjeleren and Svartdalgrotta exceed the normal maximum relationship, with subsurface cave distances that reach about one-seventh the local relief difference. Not only are these two caves situated in the valley shoulder cave location, they also both lie behind large vertical cliffs, suggesting that the effect of seismic shock is magnified even more by very steep topography. In the case of Svartdalgrotta, this overcomes the restrictive effect of an adjacent, but small, intrusive outcrop. Korallgrottan is shown at the one-eighth limit, probably because of its proximity to a thrust, despite lying essentially in a valley floor location. (However, its maximum distance from the surface is only estimated approximately). JOBshullet also lies on the one-eighth line, despite being surrounded by an enormous granite outcrop, probably because it has its cave location in a narrow ridge of marble, which is seismically very favourable. Fractures in ridge and shoul- der locations are also more likely to open farther by ice wedging and by gravitational mass movement, explaining why caves in these locations have the largest numbers of entrances per cave, creating many through caves (Faulkner 2005).

It was suggested by Faulkner (2006a) that part of Ytterlihullet achieves its exceptional (for this study area) $93 \mathrm{~m}$ subsurface cave distance because it occurs in LAK with interlayered amphibolites that acted as inception horizons. This remains a valid factor, but the cave is also situated at the eastern shoulder of Bryggfjelldal, one of the largest and deepest glaciated valleys in central Scandinavia (Fig. 4). This is $5000 \mathrm{~m}$ wide and $800 \mathrm{~m}$ deep and lies below the Okstind mountain range that has the area's largest remnant glacier. The cave is thus ideally situated to take advantage of deep fractures produced by high-magnitude seismic events that shook the area after each of its deglaciations. From Fig. 3, inception fractures formed along the observed amphibolite layers still lie within the limits of the one-eighth relationship.

From the evidence in Fig. 3, fractures are created only rarely up to the one-eighth 'limit'. Additionally, their enlargement into cave passages at the depths reached must be constrained by the extent of the marble outcrop in that area, and by the geological and topographical inheritance: passages can only develop in size (even under deglacial conditions) if there is a suitable hydraulic pathway. Deep fractures that have no route back to the surface can only fill with static water, and not enlarge. Thus, some caves with subsurface distances that are well inside the one-eighth line can be explained by a lack of suitable marble outcrop. At the extreme, areas that do not exhibit cave systems, or that contain unexpectedly shallow systems, despite containing extensive striped marble outcrops, such as Stordal near the coast (Fig. 1), may be areas of anomalously low seismicity. Indeed, the Stordal marble lies along the floor of a glacially-rounded valley 


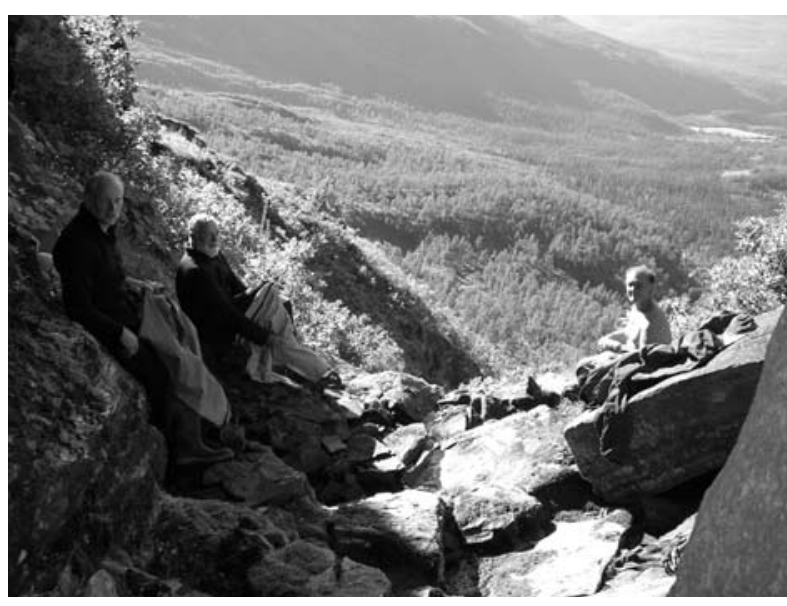

Fig. 4: Bryggfjelldal from the entrance to Naeverskardhullet. The cave system has formed at the valley shoulder location, which is favourable for the seismic creation of fractures during deglaciation.

that is surrounded by large plutons of quartz diorite and trondheimite, so that its lack of karstification can be ascribed to the contact metamorphism restriction and to its location. The many short and shallow caves at Övre Ältsvatn in Sweden commonly lie in LAK, 'remetamorphosed' in places by granitic intrusions, on a paleic surface plateau. Thus, their small dimensions probably derive from both contact metamorphism and their rather flat cave location. These reduce local seismic activity and, additionally, the paleic surface location restricts the opportunities for deep hydrogeological drainage.

The conclusion from the above commentary is that the largest positive influence on the production of long and deep inception fractures and therefore on cave dimensions is the seismic magnification that can occur at ridge and shoulder cave locations, especially if near a reactivated fault or thrust. Inception fracture depths are restricted near igneous intrusions and at coastal, valley floor and paleic surface cave locations; foliation dip has a less consistent influence.

\begin{tabular}{|c|c|c|c|c|}
\hline Cave & $\begin{array}{l}\text { Karst } \\
\text { Type }\end{array}$ & $\begin{array}{l}\text { Mean } \\
\text { tier } \\
\text { spacing } \\
(\mathrm{m})\end{array}$ & $\begin{array}{l}\text { Mean } \\
\text { shaft } \\
\text { spacing } \\
\text { (m) }\end{array}$ & $\begin{array}{l}\text { Spacing } \\
\text { ratio } \\
\text { shaft/ } \\
\text { tier }\end{array}$ \\
\hline Klausmark System & ASK & 3 & $3-30$ & $1-10$ \\
\hline Two Bridges Cave & ASK & 4 & 20 & 5 \\
\hline Hornet Pot & ASK & 6 & 30 & 5 \\
\hline Lislvatngrotta & ASK & 3 & 25 & 8 \\
\hline Tourist Cave & ASK & $4-8$ & 22 & $3-5$ \\
\hline Svartdalgrotta & LAK & 10 & $10-20$ & $1-2$ \\
\hline Neptune's Cave & ASK & $5-10$ & $10-15$ & $1-3$ \\
\hline Balcony Cave & ASK & 2 & 4 & 2 \\
\hline Toerfiellhola & VSK & 5 & $12-22$ & $2-4$ \\
\hline Øyåskjeleren & VSK & 5 & 8 & 2 \\
\hline Eiterådalgrotta & ASK & 5 & 50 & 10 \\
\hline Sirijordgrotta & VSK & 8 & 16 & 2 \\
\hline Håpgrotta & ASK & 3 & 10 & 3 \\
\hline Green Valley Cave & VSK & 2 & 5 & 2.5 \\
\hline Jordhulefjellhullet & VSK & 4 & 20 & 5 \\
\hline Pustehola & ASK & 6 & 12 & 2 \\
\hline Brown Stains Cave & ASK & 4 & 10 & 2.5 \\
\hline Sarvenvårtoehullet & ASK & 5 & 20 & 4 \\
\hline Gevirgrotta & ASK & 5 & 15 & 3 \\
\hline Sarvejaellagrottene & ASK & 8 & 12 & 1.5 \\
\hline Jegerhullet & ASK & 3 & 10 & 3 \\
\hline Etasjegrotta & VSK & 2 & 7 & 3.5 \\
\hline Invasjonsgrotta & VSK & 13 & 40 & 3 \\
\hline Anastomosegrotta & VSK & 3 & 8 & 3 \\
\hline Møllebekkgrottene & VSK & 2 & 8 & 4 \\
\hline Geitklauvgrotta & VSK & 3 & 6 & 2 \\
\hline Kompassgrotta & VSK & 5 & 10 & 2 \\
\hline Blåfellgrotta & VSK & 4 & 10 & 2.5 \\
\hline Høgligrotta & ASK & 4 & 10 & 2.5 \\
\hline Kvannlihola & VSK & 5 & $50 ?$ & 10 \\
\hline Grønndalsgrotta & LAK & 8 & 16 & 2 \\
\hline Gielasvaratjgrottan & LAK & 2 & 3 & 1.5 \\
\hline Sotsbäcksgrottan & LAK & 10 & 20 & 2 \\
\hline Korallgrottan & ASK & 4 & 18 & 4 \\
\hline SUMMARY & All & $2-13$ & $3-50$ & $1-10$ \\
\hline MEANS & & 5 & 16 & 4.6 \\
\hline
\end{tabular}

Tab. 2: Spacing between passage tiers and between shafts. For karst types, see Table 1. Caves are Listed W-E.

\section{FRACTURE SPACING}

The surveys of 34 of the more complex caves in the author's cave databases reveal (Table 2) that the mean vertical spacing between sub-horizontal phreatic passage tiers varies from $2-13 \mathrm{~m}$ (overall mean c. $5 \mathrm{~m}$ ) and the mean horizontal spacing between near-vertical shafts and joints varies from 3-50 m (overall mean c. $16 \mathrm{~m}$ ). The ratio of mean shaft spacing to mean tier spacing for each cave varies from 1-10 (overall mean c. 4.6). All these ranges appear to be independent of karst type, as previously defined. Because Marrett et al. (1999) provided evidence that fracture apertures in limestone follow a power-law scaling, it might be assumed that, at any one time and place, fracture apertures commonly decrease with depth, so that the horizontal and vertical separations between 
tectonic fractures of a particular aperture size increase with depth, i.e. they become less frequent. However, from the survey sections of the two caves with the most passage tiers in the study area ( 8 in Toerfjellhola and c. 20 in Etasjegrotta), there is little evidence of an increase in fracture spacing with subsurface cave distance, which in these cases approaches $50 \mathrm{~m}$. It is assumed therefore that within the "partially detached thin upper crustal layer" of
Davenport et al. (1989), fractures occur at essentially random intervals, but that the distance of this detachment from the contemporary surface equals the maximum subsurface cave distance. This random arrangement within an upper crustal layer contrasts with the finding of Milanović (1981, p48) that the "depth of karstification" found in boreholes in sedimentary limestone obeys an exponential law.

\section{CONCLUSIONS}

This paper has shown that the present maximum "subsurface cave distance" is commonly less than one-eighth of the depth of the local glaciated valley, suggesting that fracture generation was related to the scale of isostatic uplift and was partly determined by the magnitude of seismicity caused by the differential pressure change and differential uplift that occurred along valley walls (which are typically aligned N-S) as the Weichselian and earlier icesheets receded from $\mathrm{W}$-E.

Some stripe karst outcrops in central Scandinavia also support permanent bodies or flows of water (lakes, tarns and streams: Faulkner 2005), which suggests a sporadic lack of speleogenesis. Thus, it is concluded that tectonic activities and fractures occur in clusters along the various outcrops. As each successive glaciation deepened glacial valleys and fjords further, the ice thickness variation, and therefore the intensity of seismic shocks in some earthquake zones, must have increased during the time of the Mio-Plio-Pleistocene glaciations. However, because the valley geography remained roughly constant, each cluster of large seismic shocks remained approximately concentrated on the same position. Hence, each successive deglaciation commonly re-activated previous fracture sets, and extended them farther along, and farther below, the contemporary surface than the previous one. Because the present maximum subsurface cave distance is almost universally one-eighth the range of local relief, it seems likely that both the depth of the partially detached crustal layer and the maximum subsurface distance of cave passages also increased at oneeighth the rate of glacial valley deepening. However, acting synchronously with this deepening, there is also the probability that previous palaeo passages were removed by the erosional lowering of the surface by glacial stripping. The competition between these two processes was explored further by Faulkner (2005), to create a general Caledonide model of cave development. In this model, fractures were created by a pulse of deglacial seismicity that accompanied the recession of each ice margin, after which the presently relict phreatic passages enlarged by deglacial speleogenesis in cold water with little $\mathrm{CO}_{2}$ (Faulkner 2006b) and the mainly vadose passages enlarged during interglacial speleogenesis.

The general model was also found to be valid for karst caves in the other non-Arctic metamorphic Caledonide terranes of northern Scandinavia, southern Scandinavia, New England (USA) and in the Dalradian Supergroup outcrops in Scotland and Ireland (Faulkner 2005), where the maximum one-eighth relationship is also commonly maintained. Only in some deep caves in northern Norway (e.g. Tjoarvekrajgge, the Okshola / Kristihola system and the Greftkjelen / Greftsprekka system) is the one-eighth relationship (dramatically) exceeded. The likely explanation is that tectonic inception at such caves was promoted by longer-timescale, possibly aseismic, processes such as the long-term uplift of the Scandinavian landmass or the spreading of the Atlantic Ocean, rather than mainly by deglacial seismicity caused by rapid uplift. In at least the first two of the given examples, their relatively large subsurface cave distances may also be facilitated by the LAK nature of their (medium grade) marble outcrops, providing more opportunities for 'conventional' inception horizons to operate (c.f. Ytterlihullet, as discussed above). The island of Shetland, also within the Dalradian Supergroup, was found to have no caves within its long marble stripe karst outcrops and only small exokarst features. Hence, Shetland provides the (null) end member of a Caledonide tectonic inception series, because the Weichselian ice sheet was much thinner there, the relief is modest, and there was little deglacial seismicity. Indeed, the island was uplifted during glaciation and the present land surface is actually falling during the Holocene, so that some valley floors are now drowned by the sea to create inland waterways that are locally called voes.

If the conclusions in this paper are correct, the existence of cave passages in Caledonide marbles can be used as a proxy for the formation of tectonic fractures, and the evidence provided should be important in the field of seismology: it implies that most fracture creation arises 
from local earthquakes caused by adjustment to localscale differential ice load, and arises only exceptionally from earthquakes or slow tectonic movements caused by Scandinavian-scale isostatic uplift or by the present mid-Atlantic ridge-push that is widening the ocean. Ad- ditionally, the presence and structure of the cave passages themselves and any internal neotectonic displacements may provide a method to deduce the strength and nature of the deglacial earthquakes.

\section{ACKNOWLEDGMENTS}

This paper reports part of a wider project to study speleogenesis in Caledonide metacarbonate rocks (Faulkner 2005), for which Professor John Gunn and Dr. David Lowe were helpful and patient supervisors. Dr. Rod Gayer generously invited me to attend his lectures on Caledonian-Appalachian Tectonics at the University of Cardiff, and a field trip with Dr. Colin Davenport and his students at the University of East Anglia to study neotectonics in the Scottish Caledonides was extremely beneficial. Philippe Audra and Art and Peggy Palmer are thanked for their supportive and constructive review comments.

\section{REFERENCES}

Bakalowicz, M., 1984: Water chemistry of some karst environments in Norway.- Norsk Geografisk Tidsskrift, 38, 3-4, 209-214.

Davenport, C. A. \&P. S. Ringrose \& A. Becker \& P. Hancock \& C. Fenton., 1989: Geological investigations of late and post glacial earthquake activity in Scotland.- In: S. Gregerson \& P.W. Basham (Eds), Earthquakes at North-Atlantic Passive Margins: Neotectonics and Postglacial Rebound, 175-194.

Dehls, J. F. \& O. Olesen \& H. Bungum \& E. C. Hicks \& C. D. Lindholm \& F. Riis., 2000: 1:3000000 Neotectonic map: Norway and adjacent areas.- Geological Survey of Norway.

Ekström, G. \& M. Nettles \& G. A. Abers., 2003: Glacial earthquakes. - Science, 302, 622-624.

Faulkner, T., 2005: Cave inception and development in Caledonide metacarbonate rocks.- PhD thesis, University of Huddersfield.

Faulkner, T., 2006a: Tectonic inception in Caledonide marbles.- Acta Carsologica, 35, 1, 7-21, Ljubljana.

Faulkner, T., 2006b: Limestone dissolution in phreatic conditions at maximum rates and in pure, cold, water. - Cave and Karst Science, 33, 1, 11-20.
Lauritzen, S-E., 1981: A study of some karst waters in Norway.- Norsk Geografisk Tidsskrift, 35, 1, 1-19.

Lowe, D. J., 1992: The origin of limestone caverns: an inception horizon hypothesis.- PhD Thesis, Manchester Metropolitan University.

Lowe, D. J. \& J. Gunn., 1997: Carbonate speleogenesis: An Inception Horizon Hypothesis.- Acta Carsologica, 26, 2, 38, 457-488.

Marrett, R., O. J. Ortega \& C.M. Kelsey., 1999: Extent of power-law scaling for natural fractures in rock.Geology, 27, 9, 799-802.

Milanović, P. T., 1981: Karst Hydrogeology.- Water Resources Publications, 434pp, Littleton, Colorado.

Ringrose, P. S. \& P. Hancock \& C. Fenton \& C. A. Davenport., 1991: Quaternary tectonic activity in Scotland.- In: A. Forster \& M. G. Culshaw \& J. C. Cripps \& J. A. Little \& C. F. Moon (Eds.), Quaternary Engineering Geology, Geological Society Engineering Special Publication No. 7, 679-686. 